\title{
BERMONTININKŲ KARIUOMENĖS SUTRIUŠKINIMAS LATVIJOJE (RYGOS RAJONE) 1919 M.
}

\author{
Aivaras Petersonas (Aivars Petersons)
}

1919 m. spalio 1 d. Bermontas Jelgavoje sukvietė pasitarimą, kuriame paskelbė savo sprendimą nuversti Latvijos vyriausybę ir sukurti Pabaltijo provincijų rusų vyriausybę. Savo pajėgas Bermontas pavadino Vakarų savanorių armija (VSA). Faktiškai šios pajẻgos buvo suformuotos dar rugsejjo 5 d., tačiau tada VSA ịejo ị Judeničiaus karinių pajègų sudètį.

Spalio 6 d. visi vokiečių kariniai daliniai Pabaltijyje įsiliejo i VSA

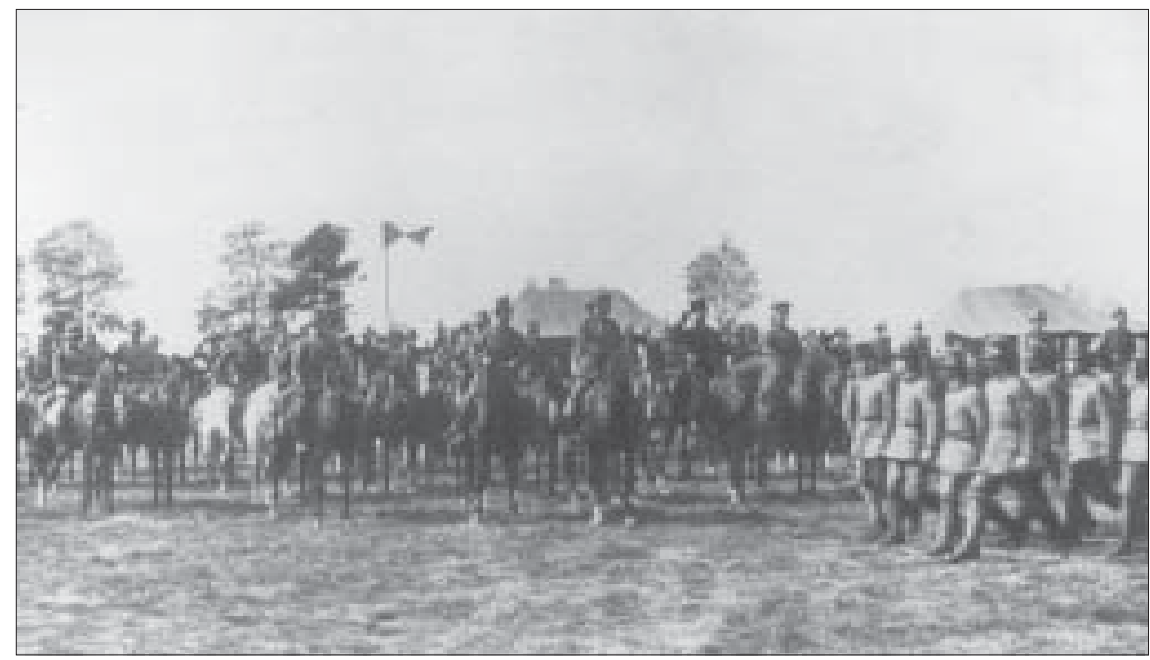

Vokiečiu ir bermontininkų kariuomenės paradas Mintaujoje 1919 rugsejo $1 \mathrm{~d}$.

ir drauge sudarẻ 50 000-52 000 žmonių kariuomenę. Faktiškai dẻl karių perdavimo Bermontui Golcas susitarè dar rugsẻjo $21 \mathrm{~d}$.

Spalio 6 d. Bermontas pasirašè įsakymą Nr. 4 dẻl puolimo ir Latvijos vyriausybei paskelbė ultimatumą. Spalio $7 \mathrm{~d}$. bermontininkų kariuomenè užèmé pradines puolimo pozicijas, buvo nutrauktas susisiekimas su Ryga.

Bermonto grupę prieš puolimą sudaré: 
1-asis gen. Kelerio korpusas (vadas pulkininkas Potockis);

10000 žm. (kovinè sudètis - 7000 žm.) Jelgavos rajone;

2-asis Virgoličiaus korpusas - 5000 žm. (kovinè sudètis - 3500 žm.) šiaurès Lietuvoje; jie atliko pagrindinių pajëgų priedangos vaidmenị;

Geležinè divizija (majoras Bišofas) Jelgavoje - 18000 žm. (kovinè sudètis - 15000 žm.);

Vokiečių legionas (jūrų kapitonas Zivertas) Bauskèje - 12000 žm. (kovinè sudètis -2 brigados -9000 žm.);

Pulkininko Dibičiaus grupè - 3000 žm. Lietuvoje;

Majoro Plehvès grupè - 3000 žm. Priekulèje.

Iš viso kovos rikiuotėje buvo 45000 žm., 118 pabūklų, 50 minosvaidžiu, 620 kulkosvaidžių, 120 lèktuvų, 3 šarvuoti traukiniai ir laivų flotilè Lielupès upejje.

Bermontas numatè:

Vokiečiu legiono jègomis pagrindinį smūgị smogti Kekavos - Pliavnijekų kryptimi, i tiltus per Dauguvą, atkirsti, apsupti ir sunaikinti Latvijos armijos grupę Uždauguvyje.

Siekiant sukaustyti ir nukreipti Latvijos pajėgų dėmesį, buvo sumanytas tiesioginis Geležinès divizijos puolimas iš Jelgavos ir Kelerio korpuso - iš Tukumo; pradinius puolimo rajonus užimti spalio $7 \mathrm{~d}$.

Latvijos armijos grupę pietų fronte sudare formuojamos (nuo liepos 15 d.) Vidžemès ir Latgalijos divizijos. Jos buvo išsidèsčiusios $30 \mathrm{~km}$ ilgio frontu nuo Dubultų (Jūrmala) iki Kekavos (prie Dauguvos); vadas pulkininkas Jorgis Zemitanas, štabo viršininkas - kapitonas Spandegas (vèliau generolas).

Frontas buvo padalytas i 2 kovos ruožus. Dešiniji - iki Jelgavos plento (imtinai) - buvo užèmę 3 Latgalijos divizijos pulkai (vadas papulkininkis $\mathrm{K}$. Berkis). Kairijij - iki Dauguvos - 5-asis ir 6-asis Vidžemès divizijos pulkai.

Iš tikrujju šiuose pulkuose aktyviems kovos veiksmams buvo paruošta tik po vieną batalioną (kiti tuo metu buvo formuojami). Iš viso turèta 11500 žm., kovinè sudètis - 5000 žm., 9 pabūklai, 68 kulkosvaidžiai, šarvuotas traukinys ir 3 šarvuotos automašinos.

Naktị ị spalio 8 d. visi daliniai kovinejje parengtyje užèmé pagrindines ir priešakines pozicijas, saugomas pagalbiniu pajègų.

Reikia pasakyti, kad priešininkus skyre $10 \mathrm{~km}$ neutralus ruožas, nustatytas sajungininkų kontrolès komisijos.

Bermontininkai puolimą pradejjo pagal savo planą - spalio $8 \mathrm{~d}$., auštant. 


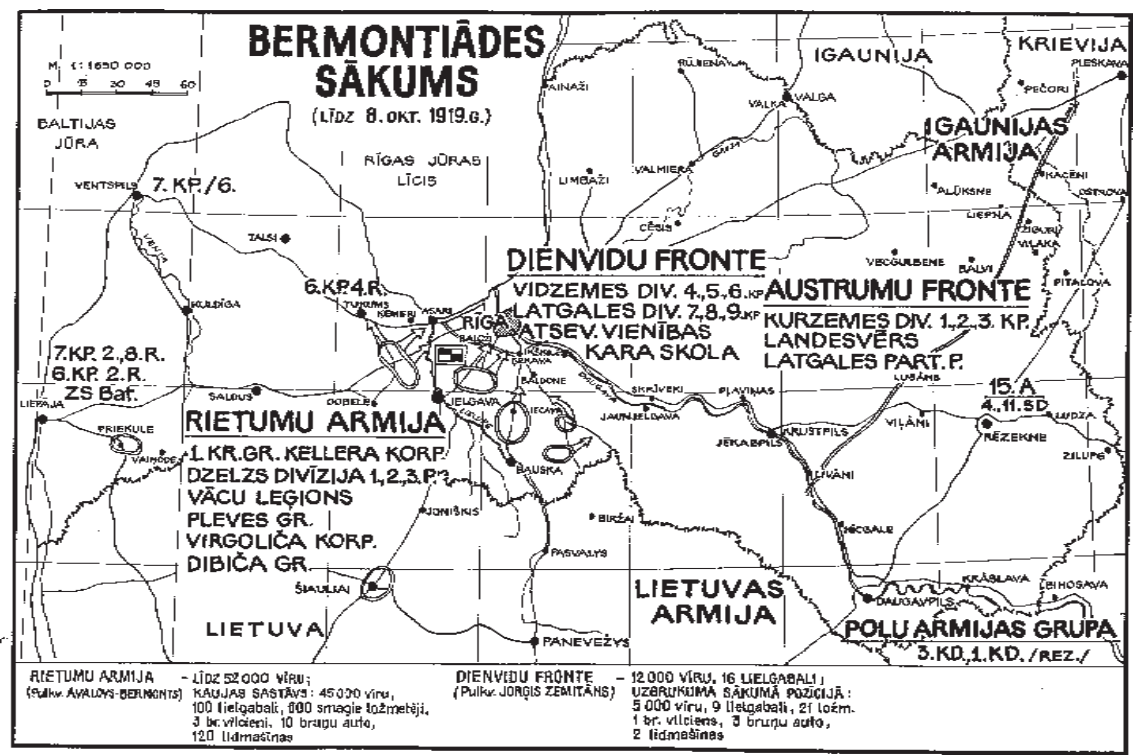

Po atkaklių gynybinių kautynių latvių daliniai spalio 8-9 d. pasitraukẻ už Dauguvos, ten ịsitvirtino, persigrupavo, pasipildẻ (daugiausia pasitelkẻ neparengtų karių) ir ruošèsi kontrpuolimui, neleisdami priešininkui įsitvirtinti Padauguvyje. Šiuo etapu bermontininkų puolimas faktiškai ir baigèsi, o jau naktị iš spalio 17 į $18 \mathrm{~d}$. patys bermontininkai buvo priversti susprogdinti tiltus per Dauguvą.

Būtina pažymėti, kad Bermonto puolimas vyko tuo pat metu, kai Judeničius puolè Petrogradą, ir netiesiogiai prisidejo prie šio puolimo nesėkmės. Jau spalio 9 d. Latvijos vyriausybė gavo Judeničiaus telegramą, kurioje Bermontas pavadintas išdaviku (kartu Judeničius parėmė Latvijos armiją padovanodamas 4-ają artilerijos bateriją).

Uždauguvio vadavimo ir bermontininkų smogiamosios grupés sutriuškinimo operacija buvo ruošiama ir vyko dviem etapais:

pirmasis - nuo spalio 14 iki $16 \mathrm{~d}$.,

antrasis - nuo lapkričio 3 iki $11 \mathrm{~d}$.

Buvo keliami tokie uždaviniai:

Dauguvos kairiajame krante užimti laikinai paliktą placdarmą, jame išskleisti pagrindines pajègas ir panaudojant apsupimo manevrą bei išnaudojant užimtaji placdarmą sutriuškinti bermontininkų pajëgas Uždauguvyje. 
Pirmam tikslui pasiekti atliktos trys desanto operacijos:

Daugavgryvoje ir Bolderajoje (dešiniajame flange);

centre išlikusiose priešininko pozicijose;

Dolès salos rajone.

Pastarosios dvi operacijos turëjo lemiamą reikšmę.

Po nesèkmingo pasitraukimo spalio 8-9 dienomis armijos vyriausiasis vadas generolas Dovydas Simonsonas jau spalio $12 \mathrm{~d}$. pakeite pietu fronto vadovybę, o Vidžemės divizijos vadu ir fronto vadu paskyrè mokymo ịstaigų viršininką, tuo metu pulkininko pareigas ejjusị Martyną Penikị, vẻliau tapusi štabo viršininku ir armijos vadu. Verta pažymėti, kad generolas Penikis buvo žymus karo istorijos ir karo meno specialistas, 1935-1940 m. dėstęs Aukštojoje karo mokykloje, dabartinès Akademijos pirmtakeje.

Naujasis vadas jau spalio 13 d. 20 val. 30 min. išleidžia ịsakymą forsuoti Dauguvą.

Sudetingiausia problema buvo artilerijos parama; be jos negali vykti tokia sudėtinga puolamujjų veiksmų rūšis kaip forsavimas. Artilerijos pabūklų santykis buvo 9 su 100 priešo naudai. Be to, Bermontas turejjo penkis kartus daugiau kulkosvaidžių. Reikèjo viltis, kad i pagalbą ateis sajungininkų laivyno eskadra Rygos ịlankoje. Padetį komplikavo tai, jog eskadros vadovybè dèl politiniu priežasčių neturèjo leidimo dalyvauti tokio pobūdžio karo veiksmuose, taigi desanto operaciją reikẻjo atidèti. Galiausiai spalio 15 d. generolui D. Simonsonui pavyksta gauti anglu pajėgų vadovybės sutikimą.

Spalio 15 d. 13 val. 15 min. eskadros dalis -5 karo laivai - užima kovines pozicijas Dauguvos žiotyse ir artilerijos ugnimi pridengia 9-ojo Rezeknès pulko sustiprintojo bataliono desantą, iš septynių upių laivų (flotilès vadas vyr. leitenantas Pukitis) išsilaipinusị prie Dauguvos žiočiu tvirtovès ir Bolderajos rajone. Netikètas smūgis visiškai pasiteisina. Užimtas platus placdarmas. I nelaisvę pateko 4 karininkai ir 300 kareivių iš Kelerio korpuso pulkų. Kaip troféjai atiteko: 20 kulkosvaidžių, 1 artilerijos pabūklas ir 2 minosvaidžiai. Savi nuostoliai: 1 žuvęs ir 5 sužeisti.

Antruoju desanto reidu i placdarmą permetamas kitas batalionas. Išsilaipinimui vadovauja 9-ojo pulko vadas papulkininkis L. Bolšteinas, būsimasis generolas ir Latvijos pasienio kariuomenès vadas. Naktị i placdarmą persikėlè 7-ojo pulko 2 batalionas. Tačiau placdarmas plečiasi tik ì vakarus. Naktị iš spalio 16 ị $17 \mathrm{~d}$. persikelia 8-asis pulkas ir Latgalijos 
divizijos štabo operatyvinè grupé, vadovaujama papulkininkio K. Berniso (būsimojo generolo, vado ir karo ministro, 1942 m. žuvusio Sibiro lageriuose).

Tačiau stinga jëgų plètoti tolesni puolimą. Pulkai suformuoti tik 50 proc. Be to, dar ịsikiša politikai, nepatenkinti savarankiškais vyriausiojo vado generolo D. Simonsono sprendimais: jis neįvykde skuboto vyriausybès sprendimo palikti Rygą. Spalio 16 d. vyriausiojo vado pareigas pradeda eiti Rytu fronto vadas pulkininkas Janis Balodis, o spalio $27 \mathrm{~d}$. štabo viršininku paskiriamas generalinio štabo pulkininkas Peteris Radzinšis, ką tik per Varšuvą atvykęs iš Ukrainos, kur dirbo Ukrainos armijos štabe. Štabo viršininkas papulkininkis Voldemaras Ozolas tapo armijos štabo operatyvinio skyriaus viršininku.

Kariuomenès komplektavimas ir vadovybès pasikeitimas operacijos pabaigą nukelia iki lapkričio. Nors iš esmès niekas nesikeičia, tačiau Simonsono ir Ozolo vardai daugelị metų bus užmiršti. Generolo laipsni Ozolas gavo tik 1937 m. Ispanijoje. 1920-1921 m. jis buvo karinis patarẻjas Lietuvoje.

Antrasis operacijos etapas prasideda lapkričio $1 \mathrm{~d}$., kai pulkai užima pradines puolimo pozicijas.

Šio etapo operacijos plane numatyta: pagrindinị smūgi smogti iš Dauguvos žiočiu placdarmo pietvakariu kryptimi, stengtasi pasiekti Tirainès rajoną ir prasibrauti ị Geležinès divizijos užnugarị, kuri buvo pagrindinė Bermonto atrama Uždauguvyje. Prie Latgalijos divizijos 7-ojo, 8-ojo ir 9-ojo pulkų prisijungia ì placdarmą atvykęs armijos rezervas Rygos péstininkų pulkas. Vèl kyla keblumų dèl artilerijos paramos. Anglijoje nupirkti ir spalio pabaigoje atgabenti artilerijos pabūklai nesukomplektuoti, sajungininkų laivyno pajëgų artileristai atsisako šaudyti, nes nematyti taikinių, o koreguotojams trūksta ryšio priemonių. Dvi paras derinami artilerijos taikiniai pagal ploto kvadratus, tačiau trūksta topografinių žemėlapių, kurie dar vienas su kitu ir tarpusavyje nesutampa. Vis dèlto reikia pasakyti, kad latvių ir anglų artileristų sukurta ypač sudètinga ugnies koregavimo sistema galiausiai pradejo veikti nepriekaištingai.

Lapkričio 3 d. 6 valandą 30 minučiu sajungininkų laivyno artilerija ir latviu artilerijos baterijos pradeda ruošti puolimą. Bermontininku artilerija ị tai atsako ugnimi. Kovos dalyviai patiria smarkią artilerijos dvikovą!

Atakos metu artilerijos ugnis nukreipiama tolyn, tačiau sẻkmė lydi tik 9-ojo pulko dalinius šiauriniame ruože. Artilerija pradeda ruošti naują 


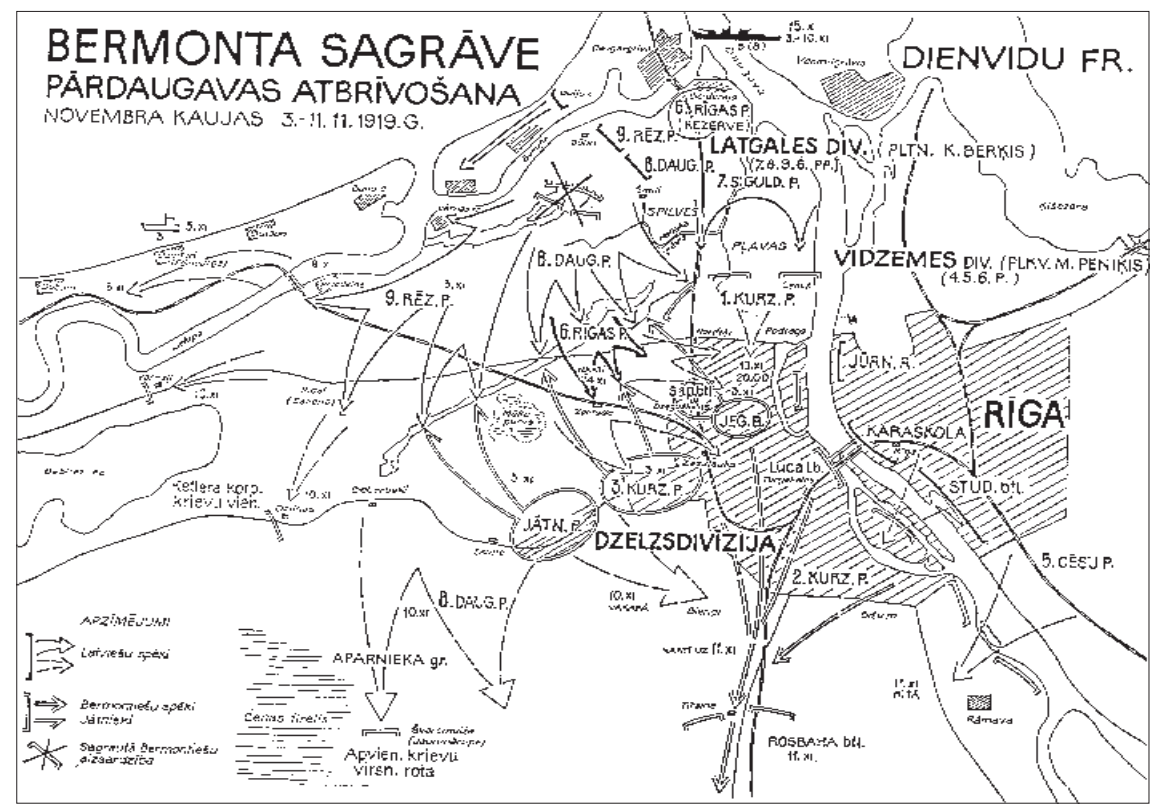

puolimą ir 12 valandą staigiai pradeda veržtis visi 8-ojo ir 9-ojo pulku batalionai. 7-ojo pulko ataka išilgai Dauguvos kranto baigiasi nesėkmingai. Geležinès divizijos kulkosvaidžių batalionas, įsitvirtinęs už betoninių cemento gamyklos sienų, apšaudo atvirą vietovę Spilvejje. Nors dienos užduotys ịvykdytos, vakare tiltų kryptimi ị mūši ịsijungia rezervinis pulkas, tačiau nakties tamsoje, neturint ryšio priemonių, mūšis nurimsta. Geležinès divizijos vadas majoras Bišofas priverčiamas mesti ị mūšį visus savo rezervus: Kuršo pulką, kavalerijos pulką ir visus atskiruosius batalionus. Be to, Kelerio korpuso pajẻgos nuo Jūrmalos ir išilgai Lielupés rengia kontratakas prieš puolančiųjų užnugarị. Jūrmalos išvalymas, artilerijos telkimas, ryšio užtikrinimas ir užnugario apsauga pareikalauja kelių dienų. Lapkričio 9 d. baigiama persigrupuoti galutiniam smūgiui. Lapkričio 10 d. 6 valandą po artilerijos apšaudymo pradedamas paskutinis šturmas. Mūšis tęsiasi visą dieną ir tik vakarop samdiniai visur pradeda trauktis. Geležinès divizijos vadas dar bando įvesti ị mūšị ką tik iš Rytprūsių atvykusi Rosbacho batalioną, tačiau jau negali sustabdyti iš beužsirišančio maišo bėgančių samdinių.

Lapkričio $11 \mathrm{~d}$. auštant kovoja tik priedangos pajėgos. Bėgantys 
bermontininkai meta viską, beje, ir 10 sunkiụjų artilerijos pabūklų.

Valstybès sostinėje, visą mėnesị buvusioje sunkių mūšių arena, įsivyravo mirtina tyla, kurią sudrumstė tik visų jos bažnyčių varpų gausmas.

Netekęs Rygos Bermontas (nuo rugsėjo 9 d. - kunigaikštis Avalovas) lapkričio 14-15 d. mėgina užimti Liepoją (Libavą), svarbų centrą ir karinę jūrų bazę. Tačiau sužlugus ir šiam puolimui, lapkričio 16 d. perduoda visus savo igaliojimus ir vadovavimą kariuomenei vokiečių rezervinio pulko vadui generolui Eberhartui, Golco ipèdiniui.

Nenutraukdama puolimo Latvijos armija lapkričio $21 \mathrm{~d}$. išvaduoja Jelgavą. Atsižvelgdama ị tai, kad prieš Latvijos kariuomenę kovoja vokiečių pajėgos, Latvijos vyriausybe lapkričio 25 d. paskelbia, jog Latvija ir Vokietija yra karo padètyje.

Tokia buvo latvių tautos herojiškos kovos dẻl savo nepriklausomybės prieš dar vieną okupantą pabaiga. Nors išsivaduojamasis karas dar nesibaigęs, lapkričio 11 d. skelbiama Tẻvynès gynèjo diena, latvių tautos didvyrio Lačplèsio diena. Šią dieną skiriamas aukščiausias Latvijos karinis trijų laipsnių ordinas - Lačplèsio ordinas.

Šiuo ordinu buvo apdovanota 2144 kartus, iš jų 11 kartų - pirmojo laipsnio ordinu.

Atskirai ordinu apdovanotas Verdeno (Prancūzijos) miestas.

Šiuo aukščiausiu kariniu ordinu apdovanoti 9 lietuvių kariai.

Antrojo laipsnio (Nr. 28) ordinu apdovanotas Lietuvos kariuomenès vyriausiasis išsivaduojamojo karo vadas Silvestras Žukauskas. Toks pat ordinas (Nr. 1405) įteiktas generolui Petrui Kubiliūnui, buvusiam latvių šaulių bataliono vadui.

Deja, esama ir tragiškų gaidų didvyrių sąrašuose. Visai neseniai išaiškèjo, kad sajungininkų karinès misijos vadovas, anglų generolas seras A. Burtas, kuris, nelaukdamas politikų sprendimo, kritiškiausiu metu suteikè pagalbą mūsų gynejjams, buvo anksčiau nei numatyta išleistas i atsargą ir neteko generolo pensijos. Anglijos vyriausybè taip pat uždraudẻ priimti karinius apdovanojimus 20 Anglijos eskadros jūrininkų, dalyvavusių mūšiuose kartu su latvių kariais. 